\title{
Budaya Organisasi Memediasi Kualitas Penerapan Sistem Informasi Akuntansi dan Kepercayaan Teknologi Informasi Pada Kinerja Karyawan
}

\author{
Luh Ayu Regita Pratami ${ }^{1}$ \\ I Gst. Ayu Eka Damayanthi ${ }^{2}$
}

${ }^{1}$ Fakultas Ekonomi dan Bisnis Universitas Udayana (Unud), Bali, Indonesia email: regitapratami29@gmail.com/Telp:+62 85739975839

${ }^{2}$ Fakultas Ekonomi dan Bisnis Universitas Udayana (Unud), Bali, Indonesia

\begin{abstract}
ABSTRAK
Sistem informasi akuntansi berbasis komputer penting diterapkan di BPR untuk menghasilkan informasi berupa laporan keuangan yang relevan, akurat dan tepat waktu. Keberlangsungan dan suksesnya suatu organisasi dapat kita lihat dari kinerja yang dimilliki oleh karyawan. Diharapkan karyawan mampu menyelesaikan tugas dan menghasilkan informasi secara tepat waktu, akurat, dan dapat dipercaya. Organisasi perlu memperhatikan faktor-faktor yang memiliki pengaruh terhadap kinerja karyawan. Penelitian ini bertujuan untuk mengetahui Pengaruh Kualitas Penerapan Sistem Informasi Akuntansi dan Kepercayaan Teknologi Informasi Pada Kinerja Karyawan dengan Budaya Organisasi sebagai Variabel Mediasi.Teknik penentuan sampel yang digunakan adalah teknik non probability sampling dengan metode purposive sampling sehingga diperoleh sampel sebanyak 90 sampel. Pengumpulan data dilakukan dengan menggunakan metode survei, yaitu menyebarkan kuesioner pada karyawan BPR di Kabupaten Gianyar. Teknik analisis yang digunakan dalam penelitian ini adalah analisis jalur (path analysis). Hasil penelitian menunjukkan bahwa Kualitas penerapan SIA dan Kepercayaan TI berpengaruh terhadap budaya organisasi di BPR Kabupaten Gianyar. Budaya organisasi, Kualitas penerapan SIA dan Kepercayaan TI berpengaruh terhadap kinerja karyawan di BPR Kabupaten Gianyar. Kualitas penerapan SIA dan Kepercayaan TI melalui budaya organisasi berpengaruh terhadap kinerja karyawan di BPR Kabupaten Gianyar. Hasil penelitian ini dapat digunakan oleh peneliti berikutnya, sebagai bahan penelitian pada bidang ilmu pengetahuan perilaku organisasi atau ilmu pengetahuan yang sejenisnya.
\end{abstract}

Kata Kunci: Kualitas penerapan sia, kepercayaan ti, kinerja karyawan, budaya organisasi

\begin{abstract}
Computer-based accounting information system is important to be applied in BPR to produce information in the form of relevant, accurate and timely financial report. Sustainability and success of an organization can be seen from the performance dimilliki by employees. It is expected that employees are able to complete the task and produce information in a timely, accurate, and reliable way. Organizations need to pay attention to factors that have an effect on employee performance. This study aims to determine the Effect of Quality of Accounting Information System Application and Trust of Information Technology on Employee Performance with Organizational Culture as Variable Mediasi.Teknik determination of the sample used is the technique of non probability sampling with purposive sampling method so that obtained sample of 90 samples. The data was collected by using survey method, which is distributing questionnaires to BPR employees in Gianyar Regency. The analysis technique used in this research is path analysis. The results showed that the quality of SIA application and IT trust influenced the organizational culture in BPR Kabupaten Gianyar. Organizational culture, Quality of SIA implementation and IT Trust influence on employee performance in BPR Kabupaten Gianyar. The quality of SIA implementation and IT belief through organizational culture
\end{abstract}


has an effect on employee performance in Rural Bank of Gianyar. The results of this study can be used by subsequent researchers, as research materials in the field of science of organizational behavior or similar science.

Keywords: Quality of accounting information system, it trust, employee performance, organizational culture

\section{PENDAHULUAN}

Era globalisasi yang ditandai dengan reformasi di bidang informasi menuntut setiap perusahaan atau organisasi agar melakukan perubahan sehingga tidak ketinggalan dalam menyerap informasi. Teknologi informasi banyak membawa perubahan dalam organisasi dan proses bisnis. Keberadaan teknologi informasi di era globalisasi, tidak dapat dipungkiri merupakan suatu kebutuhan yang penting bagi individu maupun organisasi modern. Dengan perkembangan teknologi yang semakin pesat dan cepat, karyawan dapat menggunakan teknologi dengan baik sesuai kebutuhan.

Sistem Informasi Akuntansi (SIA) adalah komponen-komponen yang saling berhubungan yang terintegrasi untuk mengumpulkan, menyimpan, dan menyebarkan data untuk tujuan perencanaan, pengendalian, koordinasi, analisis, dan pengambilan keputusan (Soudani, 2012). Pentingnya penggunaan SIA dalam menghasilkan informasi yang berkualitas dan mendukung proses pengambilan keputusan dapat meningkatkan efesiensi organisasi. Samuel (2013) mengungkapkan bahwa SIA berperan penting dalam proses pengambilan keputusan yang efektif untuk mengendalikan dan mengkoordinasikan kegiatan organisasi sehingga dapat mencapai kinerja yang lebih bagus.

Kinerja karyawan sangat memengaruhi keberhasilan sebuah perusahaan, diharapkan individu dapat menyelesaikan tugasnya tepat waktu dengan sistem 
yang ada. Menurut Mahsun dan Purwanugraha (2006:145) kinerja merupakan gambaran tentang tingkat pencapaian pelaksanaan program dan kebijakan di dalam mewujudkan sasaran, tujuan, visi dan misi dalam suatu organisasi. Kinerja karyawan dapat dilihat dari hasil kerja yang dicapai individu tersebut dalam melaksanakan tugas-tugas yang dibebankan kepadanya atas dasar kecakapan, pengalaman, serta keterampilan yang digunakan oleh individu dalam menyelesaikan suatu pekerjaan. Pencapaian kinerja juga berkaitan dengan kesesuaian antara sistem informasi yang diterapkan dengan tugas, kebutuhan dan kemampuan individu dalam organisasi tersebut. Kinerja karyawan yang tinggi dapat meningkatkan kinerja organisasi secara keseluruhan.

Kualitas sistem informasi akuntansi merupakan suatu sistem yang memiliki ciri karakteristik kualitas yang diinginkan dari sistem informasi itu sendiri (Ivari, 2005). Kualitas sistem informasi yang baik merupakan salah satu keunggulan yang dimiliki oleh perusahaan (Soudani, 2012). Penelitian yang dilakukan Kasandra (2014) menyatakan kualitas SIA berpengaruh terhadap kinerja karyawan di BPR Kabupaten Tabanan. Sedangkan penelitian Fasihat (2015) yang menyatakan kualitas SIA berpengaruh terhadap kinerja karyawan di Bank Pembangunan Daerah Daerah Istimewa Yogyakarta Syariah.

Kepercayaan pada teknologi informasi dalam melaksanakan evaluasi kinerja karyawan digunakan oleh manajemen untuk mengetahui apakah penggunaan teknologi sistem informasi berbasis komputer bisa dimanfaatkan untuk penilaian kinerja bawahan. Kepercayaan ialah sesuatu yang dibutuhkan oleh pengguna teknologi sistem informasi yang diaplikasikan untuk mencapai 
Luh Ayu Regita Pratami dan I Gst. Ayu Eka Damayanthi. Budaya...

peningkatan kinerja karyawan dalam melaksanakan kegiatan perusahaan. Penelitian sebelumnya yang dilaksanakan oleh Marlinawati (2013), Wijayanti (2013), dan Pangeso (2014) menyatakan bahwa kepercayaan teknologi informasi berpengaruh terhadap kinerja karyawan. Penelitian yang dilakukan oleh Wicaksono (2011) menyatakan bahwa kepercayaan teknologi informasi berpengaruh terhadap kinerja karyawan.

Peneliti menambahkan budaya organisasi sebagai variabel mediasi. Menurut Hariani et al. (2013) menyatakan salah satu hal yang berpengaruh terhadap kinerja dan kualitas dari sistem informasi adalah budaya organisasi. Budaya organisasi mempunyai pengaruh yang besar pada perilaku anggotaanggotanya dalam mewujudkan strategi organisasi (Hariani et al., 2013). Budaya organisasi akan memberikan suasana psikologis bagi semua anggota bagaimana mereka bekerja, bagaimana berhubungan dengan atasan maupun rekan sekerja, dan bagaimana menyelesaikan masalah merupakan wujud budaya yang khas bagi setiap organisasi. Budaya organisasi yang disosialisasikan dengan komunikasi yang baik akan dapat menemukan kekuatan menyeluruh organisasi, kinerja, dan daya saing dalam jangka panjang. Kinerja karyawan ditentukan oleh persepsi subjektif karyawan mengenai organisasi, dan persepsi keseluruhan inilah yang menjadi dasar terbentuknya budaya organisasi. Persepsi yang mendukung atau tidak mendukung ini kemudian mempengaruhi kinerja karyawan, dan kepuasan karyawan, dengan dampak yang lebih besar pada budaya.

Budaya memengaruhi kinerja karyawan dalam suatu organisasi seperti penelitian sebelumnya yang melibatkan variabel budaya organisasi yaitu pada 
penelitian Tripambudi (2014), Asfar (2009) dan Pratama (2012) yang menunjukkan hasil yang serupa bahwa budaya organisasi memiliki pengaruh yang sangat signifikan terhadap kinerja karyawan. Budaya juga memengaruhi kualitas sistem informasi akuntansi seperti penelitian Maryana (2011) yang menunjukkan pengaruh yang signifikan antara budaya organisasi dengan sistem informasi akuntansi. Maka pengaruh kualitas penerapan SIA dan kepercayaan teknologi informasi dapat meningkat melalui budaya yang tinggi dengan itu kinerja karyawan akan semakin bagus.

Salah satu lembaga keuangan yang menerapkan budaya organisasi adalah Bank Perkreditan Rakyat (BPR). Bank Perkreditan Rakyat sebagai salah satu perusahaan yang bergerak dibidang perbankan yang berbadan hukum. BPR juga merupakan salah satu jenis lembaga usaha perbankan yang mempunyai peranan penting dalam melayani kepentingan dan kebutuhan masyarakat di bidang jasa keuangan khususnya untuk usaha kecil dan mikro (UKM).

Perilaku karyawan di dalam organisasi dapat memengaruhi kepuasan nasabah. Nasabah akan merasa puas bila BPR memberikan pelayanan yang berkualitas. Kabupaten Gianyar merupakan Kabupaten yang memiliki jumlah BPR terbanyak kedua setelah Kabupaten Badung di Bali. Jumlah BPR di Kabupaten Gianyar berjumlah 32 BPR. Karyawan BPR di kabupaten Gianyar memiliki perilaku yang beraneka ragam. Ada yang kurang ramah melayani para nasabah, dan ada juga yang ramah memberikan pelayanan. Oleh sebab itu BPR harus selalu meningkatkan kinerjanya, sehingga BPR dapat tumbuh dengan sehat 
dan dapat melaksanakan fungsi sesuai dengan yang diharapkan kelompok sasarannya dan masyarakat lain pada umumnya.

BPR harus bisa memanfaatkan perkembangan teknologi untuk meningkatkan kinerja dan pelayanan BPR, agar visi dan misi bisa terlaksana dengan baik. Salah satu caranya yaitu menggunakan sistem informasi akuntansi untuk menunjang kegiatan operasional BPR. Saat ini BPR sudah menggunakan sistem pengolahan transaksi secara online seperti pembayaran rekening listrik dan air. Sehingga dari segi pelayanan, BPR tidak kalah dengan bank umum.

Berdasarkan uraian latar belakang di atas, maka terdapat rumusan masalah yang menjadi fokus penelitian ini yaitu: 1) Apakah kualitas penerapan sistem informasi akuntansi berpengaruh pada budaya organisasi di Bank Perkreditan Rakyat Kabupaten Gianyar? 2) Apakah kepercayaan teknologi informasi berpengaruh pada budaya organisasi di Bank Perkreditan Rakyat Kabupaten Gianyar? 3) Apakah budaya organisasi berpengaruh pada kinerja karyawan di Bank Perkreditan Rakyat Kabupaten Gianyar? 4) Apakah kualitas penerapan sistem informasi akuntansi berpengaruh pada kinerja karyawan di Bank Perkreditan Rakyat Kabupaten Gianyar? 5) Apakah kepercayaan teknologi informasi berpengaruh pada kinerja karyawan di Bank Perkreditan Rakyat Kabupaten Gianyar? 6) Apakah kualitas penerapan sistem informasi akuntansi melalui budaya organisasi berpengaruh pada kinerja karyawan di Bank Perkreditan Rakyat Kabupaten Gianyar? 7) Apakah kepercayaan teknologi informasi melalui budaya organisasi berpengaruh pada kinerja karyawan di Bank Perkreditan Rakyat Kabupaten Gianyar? 
Berdasarkan rumusan masalah di atas, maka tujuan penelitian ini adalah: 1) Untuk mendapatkan bukti empiris mengenai pengaruh kualitas penerapan sistem informasi akuntansi pada budaya organisasi di Bank Perkreditan Rakyat Kabupaten Gianyar, 2) Untuk mendapatkan bukti empiris mengenai pengaruh kepercayaan teknologi informasi pada budaya organisasi di Bank Perkreditan Rakyat Kabupaten Gianyar, 3) Untuk mendapatkan bukti empiris mengenai pengaruh budaya organisasi pada kinerja karyawan di Bank Perkreditan Rakyat Kabupaten Gianyar, 4) Untuk mendapatkan bukti empiris mengenai pengaruh kualitas penerapan sistem informasi akuntansi pada kinerja karyawan di Bank Perkreditan Rakyat Kabupaten Gianyar, 5) Untuk mendapatkan bukti empiris mengenai pengaruh kepercayaan teknologi informasi pada kinerja karyawan di Bank Perkreditan Rakyat Kabupaten Gianyar, 6) Untuk mendapatkan bukti empiris mengenai pengaruh kualitas penerapan sistem informasi akuntansi melalui budaya organisasi pada kinerja karyawan di Bank Perkreditan Rakyat Kabupaten Gianyar, 7) Untuk mendapatkan bukti empiris mengenai pengaruh kepercayaan teknologi informasi melalui budaya organisasi pada kinerja karyawan di Bank Perkreditan Rakyat Kabupaten Gianyar.

Berdasarkan tujuan penelitian yang telah diuraikan, adapun manfaat yang diharapkan dari penelitian ini adalah: 1) Manfaat teoritis, yakni penelitian ini dapat memberikan bukti empiris tentang Teori Technology Acceptance Model dan Theory of Attitude and Behavior dapat dikaitkan dengan kinerja karyawan pada Bank Perkreditan Rakyat di Kabupaten Gianyar melalui kualitas penerapan sistem informasi akuntansi dan kepercayaan teknologi informasi pada kinerja karyawan 
Luh Ayu Regita Pratami dan I Gst. Ayu Eka Damayanthi. Budaya...

dengan budaya organisasi sebagai variabel mediasi, serta penelitian ini diharapkan dapat dijadikan referensi untuk penelitian dalam bidang SIA di masa yang akan datang; 2) Manfaat Praktis, yakni diharapkan hasil penelitian ini mampu memberikan tambahan informasi sebagai bahan pertimbangan bagi Bank Perkreditan Rakyat (BPR) di Kabupaten Gianyar dalam meningkatkan kinerja karyawan. Hasil penelitian ini juga diharapkan dapat menjadi sumber informasi bagi peneliti selanjutnya terkait mengenai kinerja karyawan.

Kualitas sistem informasi akuntansi merupakan kualitas dari kombinasi hardware dan software dalam sistem informasi. Budaya organisasi yang kuat berkaitan dengan kualitas penerapan sistem informasi akuntansi yang unggul, karena budaya organisasi yang kuat mampu mendorong anggota organisasi mempunyai komitmen untuk peningkatan kualitas penerapan sistem informasi akuntansi perusahaan tersebut. Sehingga untuk mempertahankan budaya organisasi yang kuat maka kualitas penerapan sistem informasi yang digunakan harus baik dan unggul. Berdasarkan, uraian diatas maka hipotesis pertama adalah: $\mathrm{H}_{1}$ : Kualitas penerapan sistem informasi akuntansi berpengaruh pada budaya organisasi di Bank Perkreditan Rakyat Kabupaten Gianyar.

Kepercayaan terhadap teknologi informasi itu sendiri sangatlah penting karena adanya kepercayaan itu individu akan merasa yakin dalam melakukan pekerjaannya dan akan mendapatkan hasil yang maksimal. Kepercayaan teknologi informasi berkaitan erat dengan budaya organisasi. Peran budaya adalah untuk mengintegrasikan lingkungan internal dan beradaptasi dengan lingkungan eksternal, dan secara internal budaya organisasi harus selaras dengan strategi, struktur dan teknologi, sistem dan nilai-nilai individu dari anggota organisasi. 
Berdasarkan salah satu dimensi gabungan sifat dan budaya organisasi yaitu adaptability (adaptabilitas) yang menyatakan bahwa kemampuan organisasi dalam merespon perubahan lingkungan eksternal dengan melakukan perubahan internal organisasi. Berdasarkan uraian diatas maka hipotesis kedua adalah:

$\mathrm{H}_{2}$ : Kepercayaan teknologi informasi berpengaruh pada budaya organisasi di Bank Perkreditan Rakyat Kabupaten Gianyar.

Menurut Yamin (2014) budaya organisasi merupakan kebiasaan-kebiasaan yang terjadi dalam hirarki organisasi yang mewakili norma-norma perilaku dan diikuti oleh para anggota dalam organisasi, maka budaya organisasi akan memberikan suasana psikologis bagi semua anggota, bagaimana mereka bekerja, bagaimana berhubungan dengan atasan maupun rekan sekerja dan bagaimana menyelesaikan masalah merupakan wujud budaya yang khas bagi setiap organisasi. Menurut Supartha (2008:85) budaya organisasi kuat adalah budaya organisasi yang ideal dimana kekuatan budaya memengaruhi intensitas perilaku. Dengan adanya budaya organisasi maka dapat memengaruhi kinerja karyawan sebuah perusahaan. Berdasarkan uraian diatas maka hipotesis ketiga adalah:

$\mathrm{H}_{3}$ : Budaya organisasi berpengaruh pada kinerja karyawan di Bank Perkreditan Rakyat Kabupaten Gianyar.

Berdasarkan teori Technology Acceptance Model bahwa penggunaan sistem informasi akan meningkatkan kinerja individu atau perusahaan, dan penggunaan sistem informasi akan memermudah pemakainya dalam menyelesaikan suatu pekerjaan, hal ini dapat dikaitkan dengan kualitas penerapan sistem informasi akuntansi pada kinerja karyawan bahwa semakin meningkatnya kualitas penerapan sistem informasi akuntansi dapat menjadikan kinerja karyawan 
Luh Ayu Regita Pratami dan I Gst. Ayu Eka Damayanthi. Budaya...

tersebut lebih baik. Mc Gill et.al (2003) menyatakan terdapat hubungan positif antara kualitas sistem informasi akuntansi dengan kepuasan pengguna. Myers et al., (2007) juga menyimpulkan bahwa kualitas layanan seperti halnya dengan kualitas sistem informasi akuntansi memiliki pengaruh positif terhadap kepuasan pengguna. Hasil penelitian Kasandra (2014) menunjukkan bahwa kualitas SIA berpengaruh positif terhadap kinerja karyawan dan kinerja perusahaan. Berdasarkan uraian diatas maka hipotesis keempat adalah:

$\mathrm{H}_{4}$ : Kualitas penerapan sistem informasi akuntansi berpengaruh pada kinerja karyawan di Bank Perkreditan Rakyat Kabupaten Gianyar.

Berdasarkan teori Technology Acceptance Model menyatakan bahwa niat seseorang untuk menggunakan sistem atau teknologi ditentukan oleh dua faktor, yaitu persepsi kemanfaatan (perceived usefulness) yaitu didefinisikan sebagai tingkat dimana seseorang percaya bahwa penggunaan teknologi akan meningkatkan kinerjanya, hal ini dapat dikaitkan dengan kepercayaan atas teknologi informasi pada kinerja karyawan.

Penelitian sebelumnya yang dilakukan oleh Marlinawati (2013), Wijayanti (2013), dan Pangeso (2014) menyatakan bahwa kepercayaan teknologi informasi berpengaruh positif terhadap kinerja karyawan. Sulistyawati (2010) menyatakan bahwa adanya hubungan yang positif antara kepercayaan teknologi informasi terhadap kinerja karyawan. Utari (2012) menyimpulkan bahwa kepercayaan teknologi informasi berpengaruh positif terhadap kinerja karyawan pada Koperasi Simpan Pinjam di Kecamatan Denpasar Selatan. Berdasarkan uraian diatas maka hipotesis kelima adalah: 
$\mathrm{H}_{5}$ : Kepercayaan teknologi informasi berpengaruh pada kinerja karyawan di Bank Perkreditan Rakyat Kabupaten Gianyar.

Budaya organisasi diperlukan dalam mengambil sebuah keputusan karena budaya organisasi memiliki fungsi untuk membentuk aturan atau pedoman dalam berfikir dan bertindak dalam mencapai tujuan yang ditetapkan. Hal ini didukung oleh hasil penelitian Tripambudi (2014) menyatakan bahwa budaya organisasi memengaruhi kinerja karyawan dalam suatu organisasi. Kualitas penerapan sistem informasi akuntansi akan meningkat melalui budaya organisasi yang tinggi dengan itu kinerja karyawan akan semakin bagus. Berdasarkan uraian diatas maka hipotesis keenam adalah:

$\mathrm{H}_{6}$ : Kualitas penerapan sistem informasi akuntansi melalui budaya organisasi berpengaruh pada kinerja karyawan di Bank Perkreditan Rakyat Kabupaten Gianyar.

Sari (2009) menyatakan kepercayaan terhadap teknologi informasi akan mengarahkan individu untuk mencapai kinerja yang lebih baik. Di dalam mengevaluasi kinerja karyawan, peran budaya organisasi perlu di terapkan di sebuah lembaga keuangan karena dapat menciptakan suatu organisasi yang lebih baik dan efektif. Kepercayaan teknologi informasi akan meningkat melalui budaya organisasi yang tinggi dengan itu kinerja karyawan akan semakin bagus. Berdasarkan uraian diatas maka hipotesis ketujuh adalah:

$\mathrm{H}_{7}$ : Kepercayaan teknologi informasi melalui budaya organisasi berpengaruh pada kinerja karyawan di Bank Perkreditan Rakyat Kabupaten Gianyar. 


\section{METODE PENELITIAN}

Pendekatan yang digunakan pada penelitian ini adalah pendekatan kuantitatif. Berdasarkan tingkat eksplanasi penelitian, penelitian ini berbentuk penelitian asosiatif dengan tipe kausalitas. Lokasi atau ruang lingkup wilayah penelitian ini dilakukan pada Bank Perkreditan Rakyat yang ada di Kabupaten Gianyar, pemilihan lokasi ini dikarenakan BPR di Kabupaten Gianyar merupakan salah satu BPR terbanyak di Provinsi Bali yaitu berjumlah 32 Unit. Obyek penelitian dalam penelitian ini adalah pengaruh kualitas penerapan sistem informasi akuntansi dan kepercayaan teknologi informasi pada kinerja karyawan di Bank Perkreditan Rakyat di Kabupaten Gianyar dengan budaya organisasi sebagai variabel mediasi.

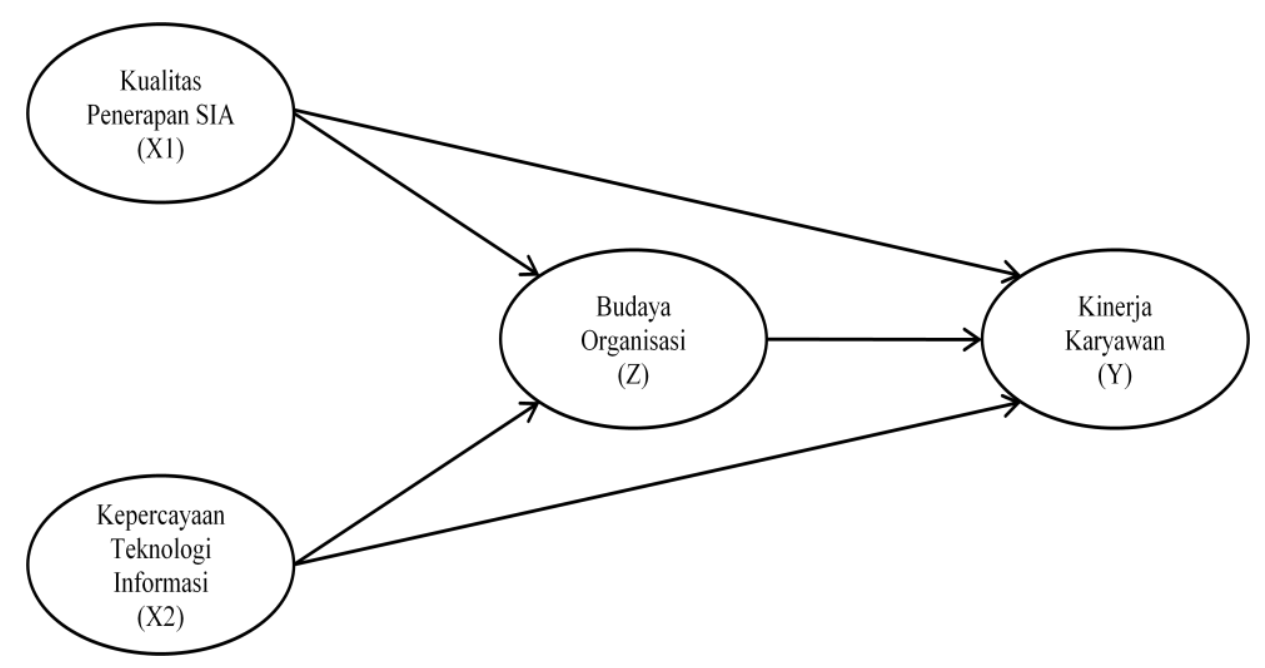

Gambar 1. Desain Penelitian

Sumber : Data Diolah, 2017

Jenis data dalam penelitian ini adalah data kuantitatif dan kualitatif. Data kuantitatif dalam penelitian ini meliputi data skor jawaban kuesioner yang terkumpul, sedangkan data kualitatif dalam penelitian ini adalah gambaran umum 
Bank Perkreditan Rakyat di Kabupaten Gianyar. Sumber data yang digunakan dalam penelitian yaitu data primer dan data sekunder. Data primer dalam penelitian ini adalah jawaban-jawaban yang diberikan oleh karyawan yang bekerja di BPR Kabupaten Gianyar dengan teknik kuesioner. Sedangkan data sekunder dalam penelitian ini adalah gambaran umum Bank Perkreditan Rakyat di Kabupaten Gianyar.

Populasi dalam penelitian ini adalah seluruh karyawan di BPR Kabupaten Gianyar. Teknik penentuan sampel yang digunakan dalam penelitian ini adalah non probability sampling dengan metode puposive sampling, dengan kriteria yang telah dikehendaki yaitu karyawan yang memanfaatkan teknologi informasi di dalam pelaksanaan tugas kesehariannya dan telah menerapkan sistem informasi akuntansi berbasis komputer. Pengambilan sampel berarti mengambil sebagian dari populasi untuk menggambarkan sifat populasi yang bersangkutan dan harus representatif. Sampel dalam penelitian ini adalah Manajer, 1 (satu) staf karyawan pada bagian pembukuan dan 1 (satu) staf karyawan pada bagian teller. Sampel dalam penelitian ini adalah sebanyak 96 orang dari 32 BPR.

Metode pengumpulan data yang digunakan dalam penelitian ini adalah metode survei dengan penyebaran kuesioner yang dilakukan dengan menyebarkan kuesioner secara langsung pada lokasi penelitian. Teknik analisis data dalam penelitian ini ialah pengujian instrument yakni uji validitas dan reliabilitas, uji asumsi klasik, dan analisis jalur. 
Luh Ayu Regita Pratami dan I Gst. Ayu Eka Damayanthi. Budaya...

\section{HASIL DAN PEMBAHASAN}

Penelitian ini dilakukan untuk mengetahui pengaruh kualitas penerapan sistem informasi akuntansi dan kepercayaan teknologi informasi melalui budaya organisasi pada kinerja karyawan di BPR Kabupaten Gianyar. Data dikumpulkan dengan menyebarkan kuesioner di BPR Kabupaten Gianyar. Kuesioner disebarkan oleh peneliti sendiri. Kuesioner disebarkan sebanyak 96 kuesioner dan kuesioner yang dikembalikan sebanyak 90 kuesioner dengan tingkat pengembalian yang digunakan sebesar 93,75. Kuesioner tidak dikembalikan sejumlah 6 kuesioner dikarenakan responden sedang ada kesibukan dan tidak berada ditempat.

Pengujian instrumen yakni uji validitas konstruksi dapat dilakukan dengan analisis faktor, yaitu dengan mengkorelasikan antar skor item instrumen dalam suatu faktor, dan mengkorelasikan skor faktor dengan skor total. Berikut hasil uji validitas yang termuat dalam Tabel 1 .

Tabel 1. Hasil Uji Validitas

\begin{tabular}{lccc}
\hline \multicolumn{1}{c}{ Variabel } & Instrumen & $\begin{array}{c}\text { Pearson } \\
\text { correlation }\end{array}$ & Keterangan \\
\hline Kinerja Karyawan & $\mathrm{Y}_{1}-\mathrm{Y}_{5}$ & $0,848-0,922$ & Valid \\
Budaya Organisasi & $\mathrm{Z}_{1}-\mathrm{Z}_{8}$ & $0,712-0,933$ & Valid \\
Kualitas Penerapan SIA & $\mathrm{X}_{1-1}-\mathrm{X}_{1-5}$ & $0,815-0,926$ & Valid \\
Kepercayaan TI & $\mathrm{X}_{2-1}-\mathrm{X}_{2-6}$ & $0,757-0,899$ & Valid \\
\hline
\end{tabular}

Sumber : Hasil Output SPSS, 2017

Berdasarkan Tabel 1. dapat dilihat hasil korelasi skor faktor dengan skor total (pearson correlation) bernilai positif > 0,3 sehingga dapat disimpulkan 
bahwa instrumen yang digunakan untuk penelitian ini memiliki validitas yang baik.

Pengujian instrumen yakni uji reliabilitas dilaksanakan untuk menguji apakah kuesioner dikatakan reliabel, reliabel diartikan jika jawaban seseorang terhadap pertanyaan-pertanyaan adalah konsisten atau stabil dari waktu ke waktu. Berikut hasil uji reliabilitas yang termuat dalam Tabel 2.

Tabel 2.

Hasil Uji Reliabilitas

\begin{tabular}{lcc}
\hline \multicolumn{1}{c}{ Variabel } & Cronbach's Alpha & Keterangan \\
\hline $\begin{array}{l}\text { Kualitas penerapan sistem informasi } \\
\text { akuntansi }\end{array}$ & 0,936 & Reliabel \\
Kepercayaan teknologi informasi & 0,927 & Reliabel \\
Budaya organisasi & 0,934 & Reliabel \\
Kinerja karyawan & 0,930 & Reliabel \\
\hline
\end{tabular}

Sumber: Hasil Output SPSS, 2017

Berdasarkan Tabel 2. di atas dapat dilihat semua nilai Cronbach Alpha $(\alpha)$ tiap variabel sebesar $>0,70$, sehingga dapat disimpulkan bahwa instrumen dalam penelitian ini memiliki konstruk atau variabel yang reliabel atau handal.

Pengujian asumsi klasik yakni uji normalitas bertujuan untuk menguji apakah dalam model regresi, variabel pengganggu atau residual memiliki distribusi normal. Penentuan normal atau tidaknya distribusi data dapat dilakukan pengujian dengan menggunakan statistic Kolmogorov-Smirnov. Hasil uji menunjukkan bahwa nilai Asymp. Sig. 0,167 pada regresi 1 dan nilai Asymp. Sig. 0,200 pada regresi 2, karena nilai Asymp. Sig. lebih besar dari alpha $(\alpha=0,05)$ maka dapat dinyatakan bahwa model uji telah memenuhi syarat normalitas data. 
Luh Ayu Regita Pratami dan I Gst. Ayu Eka Damayanthi. Budaya...

Pengujian asumsi klasik yakni uji multikolinearitas bertujuan untuk menguji apakah model regresi ditemukan adanya korelasi antar variabel eksogen. Pedoman suatu model regresi yang bebas masalah multikolinearitas adalah jika mempunyai nilai VIF (Varians Inflation Factor) kurang dari 10 dan nilai tolerance lebih dari 10\% (Ghozali, 2011:57). Hasil uji multikolinearitas pada regresi 1 dan regresi 2 untuk memiliki nilai Tolerance untuk masing-masing variabel eksogen lebih besar dari 0,1, sedangkan nilai VIF kurang dari 10. Berdasarkan hasil tersebut, maka dapat dinyatakan bahwa model uji tidak terdeteksi kasus multikolinearitas.

Pengujian asumsi klasik yakni uji heterokedastisitas bertujuan menguji apakah dalam model regresi terjadi ketidaksamaan varian dari residual satu pengamatan ke pengamatan lain. Hasil uji heterokedastisitas pada regresi 1 dan regresi 2 ditunjukkan pada menunjukkan bahwa seluruh variabel bebas tidak berpengaruh signifikan terhadap nilai absolute. Seluruh variabel memiliki nilai signifikansi yang lebih besar dari alpha $(\alpha=0,05)$. Berdasarkan hasil tersebut, maka dapat dinyatakan bahwa model uji terbebas dari kasus heterokedastisitas.

Pengujian data dilakukan dengan analisis jalur (path analysis) yaitu menguji pola hubungan yang mengungkapkan pengaruh variabel atau seperangkat variabel terhadap variabel lainnya, baik pengaruh langsung maupun pengaruh tidak langsung. Langkah pertama dalam analisis ini adalah merancang analisis jalur yakni: 1) Variabel kualitas penerapan SIA $\left(\mathrm{X}_{1}\right)$ dan kepercayaan teknologi informasi $\left(\mathrm{X}_{2}\right)$ berpengaruh terhadap budaya organisasi (Z); 2) Variabel kualitas penerapan SIA $\left(\mathrm{X}_{1}\right)$, kepercayaan teknologi informasi $\left(\mathrm{X}_{2}\right)$ dan Budaya Organisasi 
(Z) berpengaruh terhadap kinerja karyawan (Y); 3) Variabel Kualitas Penerapan SIA $\left(\mathrm{X}_{1}\right)$, Kepercayaan Teknologi Informasi $\left(\mathrm{X}_{2}\right)$ melalui Budaya Organisasi $(\mathrm{Z})$ berpengaruh terhadap Kinerja Karyawan (Y).

Langkah kedua adalah pemeriksaan terhadap asumsi yang melandasi yaitu hubungan antar variabel linier dan adiktif. Model yang digunakan adalah rekursif yaitu sistem aliran satu arah, sedangkan model resiprokal atau aliran kausal yaitu dua arah (bolak-balik) tidak dapat dianalisis. Pengaruh kualitas dari variabel endogen adalah searah dan tidak ada variabel endogen yang mempunyai pengaruh resipok (bolak-balik). Langkah ketiga yaitu pendugaan parameter atau perhitungan koefisien Path. Untuk pendugaan parameter dilakukan dengan analisis regresi melalui software SPSS 15.0 for Windows.

Berdasarkan perhitungan terhadap substruktur 1 dan 2, maka dapat diketahui besarnya pengaruh langsung, pengaruh tidak langsung dan pengaruh total antar variabel. Perhitungan pengaruh antar variabel adalah sebagai berikut :

\section{Tabel 3.}

Hasil Pengaruh Langsung dan Pengaruh Tidak Langsung serta Pengaruh Total Kualitas Penerapan SIA ( $\left.X_{1}\right)$, Kepercayaan Teknologi Informasi $\left(X_{2}\right)$, Budaya Organisasi $(Z)$, dan Kinerja Karyawan (Y)

\begin{tabular}{cccc}
\hline $\begin{array}{c}\text { Pengaruh } \\
\text { Variabel }\end{array}$ & $\begin{array}{c}\text { Pengaruh } \\
\text { Langsung }\end{array}$ & $\begin{array}{c}\text { Pengaruh Tidak Langsung } \\
\text { (Melalui Budaya Organisasi) }\end{array}$ & Pengaruh Total \\
\hline $\mathrm{X}_{1} \rightarrow \mathrm{Z}$ & $0,426\left(\mathrm{H}_{1}\right)$ & - & 0,426 \\
$\mathrm{X}_{2} \rightarrow \mathrm{Z}$ & $0,383\left(\mathrm{H}_{2}\right)$ & - & 0,383 \\
$\mathrm{Z} \rightarrow \mathrm{Y}$ & $0,624\left(\mathrm{H}_{5}\right)$ & - & 0,624 \\
$\mathrm{X}_{1} \rightarrow \mathrm{Y}$ & $0,227\left(\mathrm{H}_{3}\right)$ & $\left(\mathrm{H}_{1} \times \mathrm{H}_{5}\right) 0,265$ & $\mathrm{H}_{3+}\left(\mathrm{H}_{1 \times} \mathrm{H}_{5}\right) 0,492$ \\
$\mathrm{X}_{2} \rightarrow \mathrm{Y}$ & $0,176\left(\mathrm{H}_{4}\right)$ & $\left(\mathrm{H}_{2} \times \mathrm{H}_{5}\right) 0,238$ & $\mathrm{H}_{4+}\left(\mathrm{H}_{4} \times \mathrm{H}_{5}\right) 0,414$ \\
\hline
\end{tabular}

Sumber: Hasil Output SPSS, 2017

Berdasarkan hasil penelitian tersebut, variabel budaya organisasi menjadi penghubung yang positif antara variabel kualitas penerapan SIA dan kepercayaan teknologi informasi terhadap kinerja karyawan. 
Langkah keempat dari analisis jalur adalah melakukan pemeriksaan validasi model. Ada indikator untuk melakukan pemeriksaan validasi model, yaitu sebagai berikut :

Hasil koefisien determinasi total $=\mathrm{R}^{2} \mathrm{~m}=1-\left(\mathrm{e}_{\mathrm{e}}\right)^{2}\left(\mathrm{e}_{2}\right)^{2}$

$\mathrm{R}^{2} \mathrm{~m}=1-(0,6745)^{2}(0,3701)^{2}$

$\mathrm{R}_{\mathrm{m}}^{2}=1-(0,4555 \times 0,1369)$

$\mathrm{R}_{\mathrm{m}}{ }=1-0,0623$

$\mathrm{R}_{\mathrm{m}}{ }=0,9377$

Artinya, keragaman data yang dapat dijelaskan oleh model adalah sebesar 93,77 persen atau dengan kata lain informasi yang terkandung dalam data sebesar 93,77 persen dapat dijelaskan oleh model, sedangkan sisanya yaitu 6,23 persen dijelaskan oleh variabel lain (tidak terdapat dalam model) dan error.

Theory Triming yakni pendekatan ini dilakukan dengan membuang jalurjalur yang non signifikan agar memperoleh model yang benar-benar didukung oleh data empirik. Uji validasi pada setiap jalur untuk pengaruh langsung adalah sama dengan regresi, menggunakan nilai p dari uji t yaitu pengujian koefisien regresi variabel dibakukan secara parsiil dengan nilai masing-masing $\mathrm{X}_{1}$ adalah 4,411 dan 3,836, serta $X_{2}$ adalah 3,960 dan 3,029. Sedangkan $Z$ adalah 10,530. Selain itu yang dilihat adalah nilai p_value, sebuah model menghasilkan bentuk hubungan yang valid, dengan nilai p_value $<0,05$. Nilai p_value masing-masing adalah $\mathrm{X}_{1}$ sebesar 0,000 dan 0,000, serta $\mathrm{X}_{2}$ sebesar 0,000 dan 0,003, sedangkan $\mathrm{Z}$ sebesar 0,000 . 
Berdasarkan hasil perhitungan diperoleh taraf signifikansi penelitian untuk variabel kualitas penerapan SIA sebesar $0,000<0,05$, sehingga $\mathrm{H}_{0}$ ditolak dan $\mathrm{H}_{1}$ diterima, dengan kata lain terdapat pengaruh kualitas penerapan SIA terhadap budaya organisasi. Hal ini dikarenakan apabila adanya peningkatan kualitas penerapan sistem informasi akuntansi, maka peran budaya organisasi dapat diperkuat dalam sebuah perusahaan. Budaya organisasi yang kuat berkaitan dengan kualitas penerapan sistem informasi akuntansi yang unggul, karena budaya organisasi yang kuat mampu mendorong anggota organisasi mempunyai komitmen untuk peningkatan kualitas penerapan sistem informasi akuntansi di perusahaan tersebut. Sehingga untuk mempertahankan budaya organisasi yang kuat maka kualitas penerapan sistem informasi yang digunakan harus baik dan unggul.

Berdasarkan hasil perhitungan diperoleh taraf signifikansi penelitian untuk variabel kepercayaan teknologi informasi sebesar $0,003<0,05$, sehingga $\mathrm{H}_{0}$ ditolak dan $\mathrm{H}_{2}$ diterima, dengan kata lain terdapat pengaruh kepercayaan teknologi informasi terhadap budaya organisasi. Kepercayaan terhadap teknologi informasi itu sendiri sangatlah penting karena adanya kepercayaan itu individu akan merasa yakin dalam melakukan pekerjaannya dan akan mendapatkan hasil yang maksimal. Adanya kepercayaan terhadap teknologi yang tinggi, maka berpengaruh pada budaya organisasi yang ada diperusahaan tersebut. Kuatnya kepercayaan terhadap teknologi yang digunakan dalam sebuah perusahaan, maka dapat memperkuat budaya organisasi yang ada. 
Luh Ayu Regita Pratami dan I Gst. Ayu Eka Damayanthi. Budaya...

Berdasarkan hasil perhitungan diperoleh taraf signifikansi penelitian untuk variabel budaya organisasi sebesar $0,000<0,05$, sehingga $\mathrm{H}_{0}$ ditolak dan $\mathrm{H}_{3}$ diterima, dengan kata lain terdapat pengaruh budaya organisasi terhadap kinerja karyawan. Budaya organisasi yang kuat berkaitan dengan kinerja yang unggul karena budaya organisasi yang kuat menciptakan suatu tingkat motivasi dalam diri, memberikan struktur dan kontrol yang mendorong anggota organisasi mempunyai komitmen terhadap kemajuan organisasi. Adanya budaya organisasi yang dapat dijadikan pedoman dalam sebuah perusahaan maka dapat meningkatkan kinerja karyawan di perusahaan tersebut. Sehingga untuk mempertahankan budaya organisasi yang kuat maka kinerja karyawan harus lebih meningkat.

Berdasarkan hasil perhitungan diperoleh taraf signifikansi penelitian untuk variabel kualitas penerapan SIA sebesar $0,000<0,05$, sehingga $\mathrm{H}_{0}$ ditolak dan $\mathrm{H}_{4}$ diterima, dengan kata lain terdapat pengaruh kualitas penerapan SIA terhadap kinerja karyawan. Mc Gill et.al (2003) menyatakan terdapat hubungan positif antara kualitas sistem informasi akuntansi dengan kepuasan pengguna. Myers et al., (2007) juga menyimpulkan bahwa kualitas layanan seperti halnya dengan kualitas sistem informasi akuntansi memiliki pengaruh positif terhadap kepuasan pengguna. Hasil penelitian Kasandra (2014) menunjukkan bahwa kualitas SIA berpengaruh positif terhadap kinerja karyawan dan kinerja perusahaan. Sehingga semakin bagus kualitas penerapan SIA akan dapat menjadikan kinerja karyawan tersebut semakin meningkat. 
Berdasarkan hasil perhitungan diperoleh taraf signifikansi penelitian untuk variabel kepercayaan teknologi informasi sebesar $0,003<0,05$, sehingga $\mathrm{H}_{0}$ ditolak dan $\mathrm{H}_{5}$ diterima, dengan kata lain terdapat pengaruh kepercayaan teknologi informasi terhadap kinerja karyawan. Penelitian sebelumnya yang dilakukan oleh Sulistyawati (2010), Utari (2012), Marlinawati (2013), Wijayanti (2013), dan Pangeso (2014) menyatakan bahwa kepercayaan teknologi informasi berpengaruh positif terhadap kinerja karyawan. Kepercayaan merupakan hal yang diperlukan karyawan pemakai teknologi informasi yang baru agar mereka merasa bahwa teknologi informasi yang baru dapat meningkatkan kinerja karyawan dalam menjalankan kegiatan organisasi atau perusahaan. Sehingga semakin tinggi kepercayaan pada teknologi informasi maka semakin baik kinerja karyawan tersebut.

Berdasarkan hasil perhitungan uji sobel, maka diketahui $\mathrm{Z}_{\text {score }}(4,053)$ sudah lebih besar daripada $\mathrm{Z}_{\text {tabel }}(1,96)$. Jadi dapat dinyatakan bahwa $\mathrm{H}_{0}$ di tolak dan $\mathrm{H}_{6}$ diterima, artinya terdapat pengaruh kualitas penerapan SIA terhadap kinerja karyawan melalui budaya organisasi. Budaya organisasi diperlukan dalam mengambil sebuah keputusan karena budaya organisasi memiliki fungsi untuk membentuk aturan atau pedoman dalam berfikir dan bertindak dalam mencapai tujuan yang ditetapkan. Hal ini didukung oleh hasil penelitian Tripambudi (2014) menyatakan bahwa budaya organisasi memengaruhi kinerja karyawan dalam suatu organisasi. Kualitas penerapan sistem informasi akuntansi akan meningkat melalui budaya organisasi yang tinggi dengan itu kinerja karyawan akan semakin bagus. 
Luh Ayu Regita Pratami dan I Gst. Ayu Eka Damayanthi. Budaya...

Berdasarkan hasil perhitungan uji sobel, maka diketahui $\mathrm{Z}_{\text {score }}(3,693)$ sudah lebih besar daripada $\mathrm{Z}_{\text {tabel }}(1,96)$. Jadi dapat dinyatakan bahwa $\mathrm{H}_{0}$ di tolak dan $\mathrm{H}_{7}$ diterima, artinya terdapat pengaruh kepercayaan teknologi informasi terhadap kinerja karyawan melalui budaya organisasi. Kepercayaan terhadap teknologi informasi dalam mengevaluasi kinerja karyawan diperlukan oleh manajemen untuk memastikan bahwa teknologi informasi berbasis komputer dapat digunakan untuk mengendalikan kinerja para karyawan. Di dalam mengevaluasi kinerja karyawan, peran budaya organisasi perlu di terapkan di sebuah lembaga keuangan karena dapat menciptakan suatu organisasi yang lebih baik dan efektif. Hal ini didukung oleh hasil penelitian Asfar (2009) yang menunjukkan hasil bahwa budaya organisasi memengaruhi kinerja karyawan dalam suatu organisasi. Kepercayaan teknologi informasi akan meningkat melalui budaya organisasi yang tinggi dengan itu kinerja karyawan akan semakin bagus.

\section{SIMPULAN}

Berdasarkan hasil penelitian, analisis dan interprestasi data, maka kesimpulan yang dapat diberikan adalah sebagai berikut: 1) Kualitas penerapan SIA berpengaruh terhadap budaya organisasi di BPR Kabupaten Gianyar. Sehingga untuk mempertahankan budaya organisasi yang kuat maka kualitas penerapan sistem informasi yang digunakan harus baik dan unggul; 2) Kepercayaan teknologi informasi berpengaruh terhadap budaya organisasi di BPR Kabupaten Gianyar. Sehingga adanya kepercayaan terhadap teknologi informasi yang diadaptasi dari eksternal dapat mempengaruhi budaya organisasi perusahaan tersebut; 3) Budaya organisasi berpengaruh terhadap kinerja karyawan di BPR 
Kabupaten Gianyar. Sehingga dengan adanya budaya organisasi maka dapat memengaruhi kinerja karyawan; 4) Kualitas penerapan SIA berpengaruh terhadap kinerja karyawan di BPR Kabupaten Gianyar. Hal ini berarti semakin bagus kualitas penerapan SIA, maka kinerja karyawan juga akan semakin meningkat; 5) Kepercayaan teknologi informasi berpengaruh terhadap kinerja karyawan di BPR Kabupaten Gianyar. Hal ini berarti semakin tinggi kepercayaan pada teknologi informasi maka semakin baik kinerja karyawan; 6) Terdapat pengaruh antara kualitas penerapan SIA melalui budaya organisasi pada kinerja karyawan di BPR Kabupaten Gianyar. Hal ini berarti kualitas penerapan SIA meningkat melalui budaya organisasi yang tinggi dengan itu kinerja karyawan akan semakin bagus; 7) Terdapat pengaruh antara kepercayaan teknologi informasi melalui budaya organisasi pada kinerja karyawan di BPR Kabupaten Gianyar. Hal ini berarti kepercayaan teknologi meningkat melalui budaya organisasi yang tinggi dengan itu kinerja karyawan akan semakin bagus.

Berdasarkan hasil dan pembahasan serta kesimpulan pada penelitian ini, adapun saran-saran yang dapat diberikan dalam penelitian ini, yaitu: 1) Para karyawan di BPR Kabupaten Gianyar diharapkan bisa memanfaatkan teknologi informasi dalam melaksanakan tanggung jawab dengan baik sehingga mampu meningkatkan kinerja karyawan di BPR Kabupaten Gianyar; 2) Harus adanya hubungan yang harmonis antara sesama karyawan sehingga budaya organisasi di BPR Kabupaten Gianyar menjadi lebih kuat; 3) BPR di Kabupaten Gianyar sebaiknya memberikan pelatihan kepada karyawannya agar sistem yang disediakan mudah digunakan sehingga mampu meningkatkan kualitas penerapan 
Luh Ayu Regita Pratami dan I Gst. Ayu Eka Damayanthi. Budaya...

SIA; 4) Para karyawan di BPR Kabupaten Gianyar diharapkan mampu menyelesaikan pekerjaannya dengan tepat waktu sehingga kepercayaan terhadap teknologi informasi komputer dapat memenuhi kebutuhannya dalam bekerja.

\section{REFERENSI}

Asfar, Halim Dalimunthc. 2009. Pengaruh Budaya Organisasi Terhadap Kinerja Pegawai. Skripsi Fakultas Ilmu Sosial dan Politik Universitas Sumatera.

Bailey, J. E. and S.W. Pearson. 1983. Development of a Tool For Measuring and Analyzing Computer User Satisfaction. Management Science, 29(5) : 530545.

Choe, Jong Min. 1996. "The Relationship Among Perfomance of Accounting Information Systems, Influence Factor and Evolution Level of Information Systems". Journal of MIS. Spring. 12(4)

Davis, Fred D.1989. Perceived Usefulness, Perceived Ease of Use and User Acceptance of Computer Technology. MIS Quertely. September.

DeLone, W. H., and Mclean, E. R. 2010. Information System Success: The Quest for the Dependent Variable, Information System Research, 3(1): 60-95.

Fishbein dan Ajzen, 1975. Belief, Attitude, Intentions and Behavior: an introduction to theory and research. California: Addison-Wesley Publishing Company, Inc.

George, Ndemo Ochoti., Elijah, Maronga Dr. Stephen., Muathe Dr. Robert, Nyamao., and Peter, Kibet. 2012. Factors Influencing Employee Performance Appraisal System. International Journal of Business and Social Science. 3(20), pp: 37-46.

Ghozali, Imam. 2011. Aplikasi Analisis Multivariate dengan Program SPSS, Edisi ke-5. Semarang: Universitas Diponegoro.

Gupta M.P, Kanungo S, Kumar R and Sahu G.P,2007. “A Study of Information Technology Efectiveness in Select Government Organizations in India". Journal for Decision Makers. 32(2)

Haaland, Stephanie, Paulo Goelzer dan Daniel R. Denison. 2003. Corporate Culture and Organizational Effectiveness: Is Asia Different From the Rest of the World. Organizational Dynamics 33(1)

Handayani, Rini. 2007, "Analisis Faktor-Faktor yang Mempengaruhi Minat Pemanfaatan Sistem Informasi”. SNA X. UNHAS Makasar 26-28 Juli. STIE Atma Bhakti Surakarta. 
Hariani, D., Purbandari, T., dan Mujilan, A. 2013. Dukungan Manajerial dan Budaya Organisasi untuk Menuju Efektivitas Sistem Informasi. JRMAI Jurnal Riset Manajemen dan Akuntansi, 1(2), 29-36

Henny Hendarti dan Anderes Gui, 2008. Korelasi Antara Efektivitas Sistem Informasi Penjualan Dengan Kinerja User. Seminar Nasional Aplikasi Teknologi Informasi. Yogyakarta.

Ivari, J. 2005. An Empirical Test of the DeLone-McLean Model of Information System Success. The Data Basa for Advances in Information System Spring. 36(2)

Jumali, Salman.2005. "Kepercayaan terhadap Teknologi Sistem Informasi Baru dalam Evaluasi Kinerja Individual”. Kumpulan materi Simposium Nasional Akuntansi VIII. Solo.15-16 September.

Marlinawati, Ni Made Ayu. 2013. Pengaruh Penggunaan Teknologi Informasi, Efektivitas Sistem Informasi Akuntansi, Kepercayaan atas Sistem Informasi Akuntansi, dan Kesesuaian Tugas pada Kinerja Karyawan Lembaga Perkreditan Desa Di Kabupaten Badung. E-Journal Akuntansi Universitas Udayana.

Maryana, Meida 2011. Pengaruh Budaya Organisasi terhadap Sistem Informasi Akuntansi dan Implikasinya pada Pengendalian Internal (Survey pada 10 KPP Bandung Kanwil Jawa Barat 1). Jurnal Akuntansi Universitas Komputer Indonesia.

McGill, Tanya, Hobbs, Valerie, \& Klobas, Jane. 2003. "User-Developed Applications and Information Systems Success: a Test of DeLone and McLean's Model” Information resource Management Journal, 16(1): 2445

Myers, Barry L, Kappelman, Leon A. \& Prybutok, Victor. R. 2007. A Comprehensive Model for Assesing the Quality of the Information System Function: Toward a Theory for Information System Assement, Information Resource Management Journal. Winter. 10 (1): 6-25.

Nurcaya, I Nyoman. 2010. Informasi Sebagai Faktor Sukses Kritis Organisasi. Dalam Buletin Studi Ekonomi. 15 (1) :35-37

Pratama, Yoga. 2012. Pengaruh Budaya Organisasi Terhadap Kinerja Pegawai Pada Kantor Kecamatan Nanggung Kabupaten Bogor. Skripsi Fakultas Ilmu Sosial dan Politik Universitas Indonesia.

Pratiwi, Riska. 2012. Pengaruh Budaya Organisasi Terhadap Kinerja Pegawai pada Kantor Pelayanan Kekayaan Negara dan Lelang Makasar. Skripsi Fakultas Ekonomi dan Bisnis Universitas Hasanuddin. 
Saka Sumarsa, Putu dan Noviari, Naniek. 2013. Pemanfaatan Teknologi Informasi, Kepercayaan, dan Kompetensi Pada Penerapan Teknik Audit Sekitar Komputer. E-Jurnal Akuntansi Universitas Udayana, 4(3):640-654

Samuel, Nzomo. 2013. Impact Of Accounting Information Systems On Organizational Effectiveness Of Automobile Companies In Kenya. Research Project Submitted In Fulfillment For The Requirement Of The Award Of Degree In Master Of Business Administration University Of Nairob.

Sari, Maria. M. Ratna. 2009. Pengaruh Efektivitas Penggunaan dan Kepercayaan terhadap Teknologi Sistem Informasi Akuntansi terhadap Kinerja Individual pada Pasar Swalayan di Kota Denpasar. Jurnal Ilmiah Akuntansi dan Bisnis. 4(1)

Sobel, M. E. 1982. Asymptotic Confidence Intervals for Indirect Effects in Structural Eequation Models. In S. Leinhardt (Ed.), Sociological Methodology. Washington DC: American Sociological Association.

Soudani, Siamak Nejadhosseini. 2012. The Usefulness of an Accounting Information System for Effective Organizational Performance. International Journal of Economics and Finance. 4(5): 136-143

Sugeng dan Nur Indriantoro. 1998. Peran Faktor Kecocokan Tugas Teknologi dalam Memperoleh Pengaruh Positif Teknologi Informasi Terhadap Kinerja Individual. Jurnal Ekonomi dan Bisnis. (13):3.

Sulaksono, Tri. 2005. Budaya Organisasi dan Ketidakpastian Lingkungan Sebagai Variabel Moderating Dalam Hubungan Antara Evaluasi Atasan Terhadap Tekanan Kerja dan Kepuasan Bawahan. Tesis. Magister Akuntansi Program Pasca Sarjana Universitas Diponogoro Semarang..

Tjhai fung Jing. 2003. “Analisis Faktor-faktor yang Mempengaruhi Pemanfaatan Teknologi Informasi terhadap Kinerja Akuntan Publik”. Jurnal Bisnis dan Akuntansi. 5(1):1-26

Tripambudi, Norman. 2014. Pengaruh Budaya Organisasi dan Struktur Organisasi pada Sistem Informasi Akuntansi dan Dampaknya terhadap Kualitas Informasi. (Doctoral dissertation, Fakultas Ekonomi dan Bisnis).

Venkatesh V., Moris, M.G., Davis, G.B., and Davis F.D. 2003. "User Acceptance of Information Technology: Toward a Unified View". MIS Querterly. 27(3): 425-475

Wijayanti, Tutut. 2013. Pengaruh Teknologi Sistem Informasi Akuntansi, Kepercayaan Teknologi Sistem Informasi, dan Kepuasan pengguna Terhadap Kinerja Individual (Studi pada Dinas Pendapatan Pengelolaan keuangan Daerah dan Aset Daerah (DOOKAD) Kabupaten Grobogan). Jurnal Akuntansi Universitas Muhammadiyah Surakarta. 
ISSN: 2302-8556

E-Jurnal Akuntansi Universitas Udayana Vol.22.2. Februari (2018): 1032-1058

Xu, Hongjiang and Dandong Lu. 2003. The Critical Success Factors For Data Quality In Accounting Information System Different Industries perspective. IACIS.

Yamin, Muh. 2014. Pola Budaya dan Kinerja Organisasi Publik (Studi Pada Pemerintah Kota Kendari). Jurnal Birokrat Ilmu Administrasi Publik. 1(2) 